\title{
GATOR1 complex: the common genetic actor in focal epilepsies
}

${ }^{1}$ Department of Medical and Surgical Sciences-Medical Genetics Unit, Università degli Studi di Bologna Azienda Ospedaliera Sant'OrsolaMalpighi, Bologna, Italy ${ }^{2}$ IRCCS Istituto delle Scienze Neurologiche, Bologna, Italy ${ }^{3}$ Department of Biomedical and Neuromotor Sciences, University of Bologna, Bologna, Italy

\section{Correspondence to} Dr Francesca Bisulli, Department of Biomedical and Neuromotor Sciences, IRCCS Istituto delle Scienze Neurologiche, Azienda USL di Bologna, University of Bologna, Pad G1-Bellaria Hospital, Via Altura 3, Bologna 40139, Italy; francesca.bisulli@unibo.it

Received 4 March 2016 Accepted 28 April 2016 Published Online First 19 May 2016
CrossMark

To cite: Baldassari $S$, Licchetta $L$, Tinuper $P$, et al. $J$ Med Genet 2016;53: 503-510.

\author{
Sara Baldassari, ${ }^{1}$ Laura Licchetta, ${ }^{2,3}$ Paolo Tinuper, ${ }^{2,3}$ Francesca Bisulli, ${ }^{2,3}$ \\ Tommaso Pippucci ${ }^{1}$
}

\section{ABSTRACT}

The mammalian or mechanistic target of rapamycin (mTOR) signalling pathway has multiple roles in regulating physiology of the whole body and, particularly, the brain. Deregulation of mTOR signalling has been associated to various neurological conditions, including epilepsy. Mutations in genes encoding components of Gap Activity TOward Rags 1 (GATOR1) (DEPDC5, NPRL2 and NPRL3), a complex involved in the inhibition of the mTOR complex 1 (mTORC1), have been recently implicated in the pathogenesis of a wide spectrum of focal epilepsies (FEs), both lesional and non-lesional. The involvement of DEPDC5, NPRL2 and NRPL3 in about $10 \%$ of FEs is in contrast to the concept that specific seizure semiology points to the main involvement of a distinct brain area. The hypothesised pathogenic mechanism underlying epilepsy is the loss of the inhibitory function of GATOR1 towards mTORC1. The identification of the correct therapeutic strategy in patients with FE is challenging, especially in those with refractory epilepsy and/or malformations of cortical development (MCDs). In such cases, surgical excision of the epileptogenic zone is a curative option, although the long-term outcome is still undefined. The GATOR $1 / \mathrm{mTOR}$ signalling represents a promising therapeutic target in FEs due to mutations in mTOR pathway genes, as in tuberous sclerosis complex, another MCD-associated epilepsy caused by mTOR signalling hyperactivation.

\section{INTRODUCTION}

Mammalian or mechanistic target of rapamycin (mTOR) is an ubiquitously expressed serine/threonine kinase regulating cell growth, proliferation, metabolism, motility, death (through apoptosis and autophagy), protein synthesis and transcription. ${ }^{1-3}$ Brain-specific roles include regulation of synaptic plasticity and learning, neurogenesis and dendritic/ axonal morphology. ${ }^{4-7}$ The protein is a catalytic component of two different complexes, mTORC1 (mTOR complex 1) and mTORC2 (mTOR complex 2), in which mTOR associates with two regulatory subunits: Raptor and Rictor, respectively (figure 1). ${ }^{3}$ mTORC1 represents one of the most important regulators of cell growth. ${ }^{1}$ The activity of this complex is controlled by numerous factors (insulin, growth factors, amino acids and oxidative stress) ${ }^{8} 9$ acting through various protein signalling pathways (figure 1). ${ }^{6}$ One of these pathways recruits the GATOR (Gap Activity TOward Rags) complex, involved in the amino acid sensing activity (figure 1). ${ }^{10}$ GATOR complex is composed of two subcomplexes, GATOR1 and GATOR2, which function as negative and positive regulators of mTORC1, respectively (figure 1). ${ }^{10-13}$ The former includes DEPDC5 (DEP domain-containing protein 5), NPRL2 (nitrogen permease regulator 2-like protein) and NPRL3 (nitrogen permease regulator 3-like protein) proteins, the latter MIOS (missing oocyte, meiosis regulator, homologue), SEH1L (SEH1 like), SEC13 (SEC13 homologue), WDR24 (WD repeat domain 24) and WDR59 (WD repeat domain 59). The role of each protein in these complexes has still to be fully clarified, but the conservation of the mTOR pathway architecture across different species suggests that each partner of the complex carries out fundamental functions. ${ }^{14}$ Recently, mutations in the genes encoding the components of the GATOR1 subcomplex have been associated with several genetic focal epilepsy (FE) syndromes, including autosomal-dominant nocturnal frontal lobe epilepsy (ADNFLE, MIM 600513), recently renamed as autosomal-dominant sleep-related hypermotor epilepsy; ${ }^{15}$ epilepsy with auditory features (EAF, also known as lateral temporal lobe epilepsy, TLE, MIM 600512); familial FE with variable foci (FFEVF, MIM 604364). ${ }^{16-20}$ DEPDC5 mutations have also been recently described in patients manifesting rolandic epilepsy or epileptic spasms. ${ }^{2122}$

\section{MUTATIONS OF GATOR1 IN FE SYNDROMES}

Epilepsy is a widespread neurological disorder affecting about $1 \%$ of the global population. ${ }^{23}$ In FE, seizures originate from a limited area of the brain (the epileptogenic zone, EZ). FEs account for nearly $60 \%$ of all epileptic syndromes, and can be caused by genetic as well as acquired factors. ${ }^{24} 25$ Paradigmatic FE genetic syndromes (EAF, ADNFLE and FFEVF) have been associated with mutations in a number of genes (figure 2) coding for proteins implicated in different brain functions (eg, synapse development and transmission or neuronal excitability). ${ }^{17-20} \quad{ }^{26-32}$ The identification of mutations in GATOR1 genes in all these epileptic syndromes opens the interesting scenario of defects of the same pathway underlying different epilepsy phenotypes (figure 3 and table 1 provide a summary of the mutations identified so far). ${ }^{16-18} 202133-41$

Mutations in DEPDC5, first identified in seven out of the eight FFEVF families linked to chromosome $22 \mathrm{q} 12,{ }^{18}$ were subsequently implicated in the $5 \%-37 \%$ of a broad range of FEs, including NFLE and TLE. ${ }^{16}{ }^{36}$ More recently, the description of NPRL 2 and NPRL3 mutations in patients with FE confirmed the involvement of the entire GATOR1 complex in the pathogenesis of different FE syndromes. ${ }^{1920}$ Collectively, the data published so far indicate that mutations in genes encoding the GATOR1 complex are the most frequent genetic 


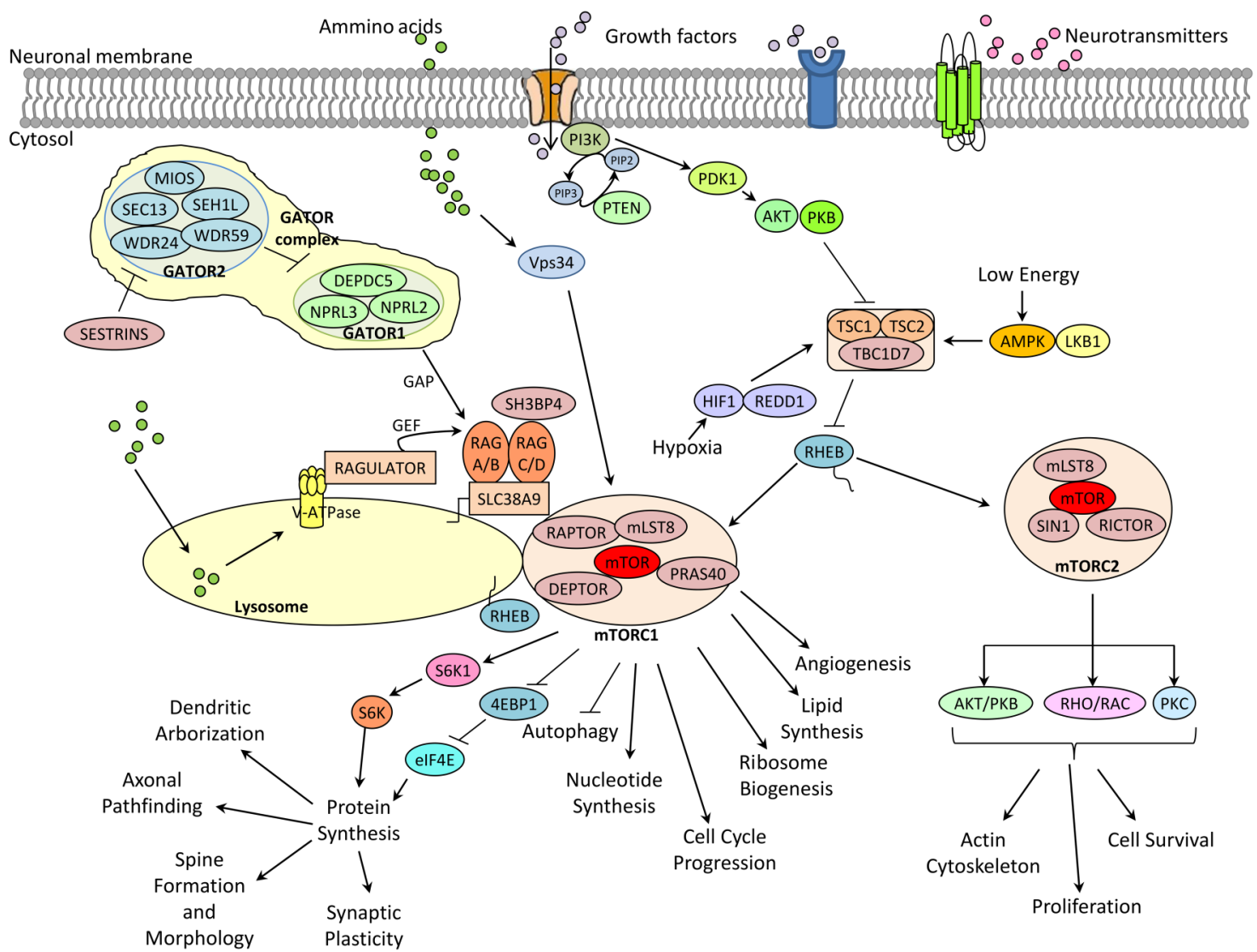

Figure 1 Schematic representation of mTOR signalling pathway. mTOR, mammalian or mechanistic target of rapamycin.

cause of FEs, globally accounting for $9 \%$ of the cases. ${ }^{20}$ Mutations in these genes may show a wide interfamilial and intrafamilial variability in epilepsy phenotypes, as exemplified by FFEVF. Within a family, the same mutation can be associated with lesional and non-lesional epilepsy: in only some of the affected members, brain MRI disclosed malformations of cortical development (MCDs), in particular focal cortical dysplasia (FCD) type IIb. ${ }^{19} 20{ }^{38-41}$ FCDs are the most common cause of medically refractory epilepsy. ${ }^{45}$ Surgery represents a highly effective treatment in these patients and requires a comprehensive presurgical assessment for identification of the EZ, especially in the $15 \%$ of 'lesion negative' cases where subtle FCD are detected only by histology. ${ }^{46}$ The aetiology of FCDs is largely unknown, but the identification of mutations in GATOR1-encoding genes in patients with such MCDs suggests an alteration of mTOR signalling pathway. Interestingly, other

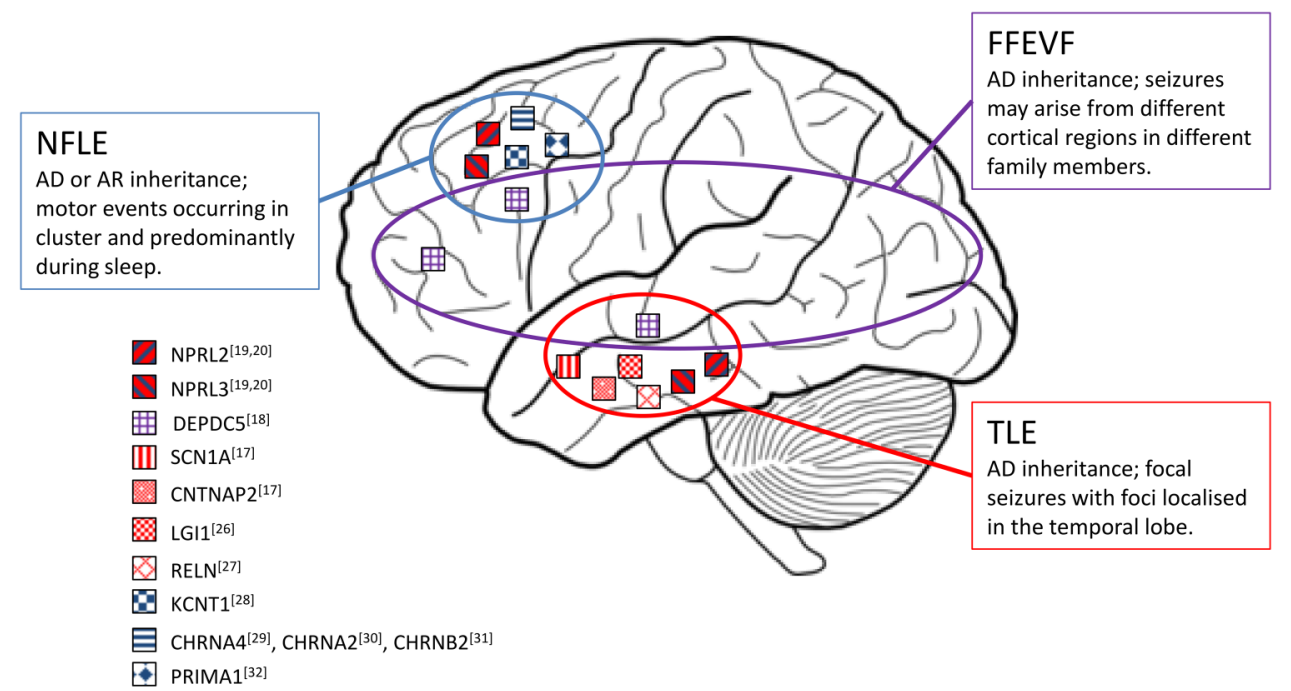

Figure 2 Genes mutated in the major focal epilepsy syndromes. The localisation of the squares on the brain image is related to the cortical lobe involved in the epileptic discharges in the major FEs to which these genes have been associated. AD, autosomal dominant; $A R$, autosomal recessive; NFLE, nocturnal frontal lobe epilepsy; TLE, temporal lobe epilepsy; FFEVF, familial focal epilepsy with variable foci. 

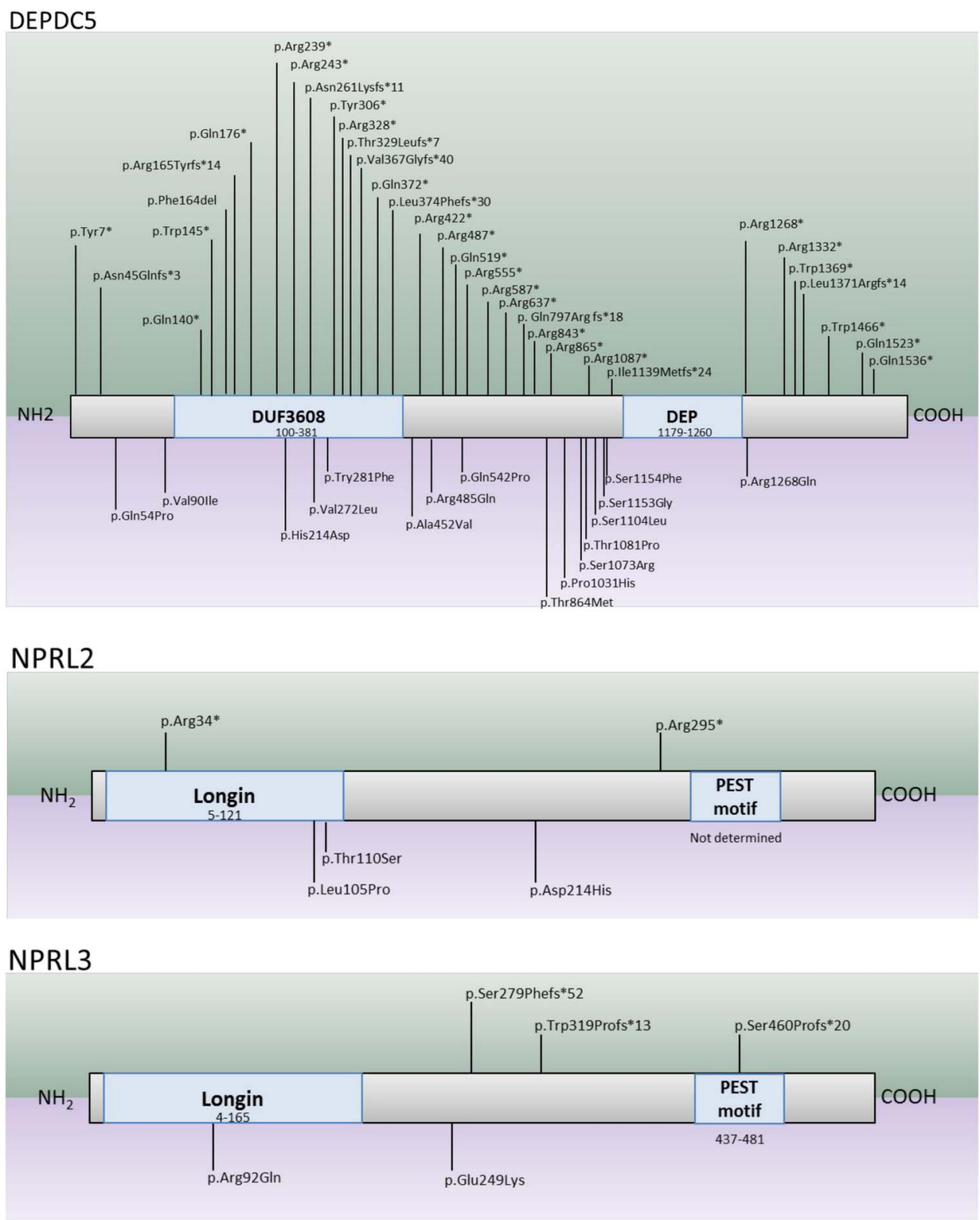

Figure 3 Schematic representation of Gap Activity TOward Rags 1 (GATOR1) genes and published mutations. The mutations reported are subdivided in loss-of-function mutations (upper panel in each gene representation) and missense mutations (lower panel). Splicing affecting mutations listed in table 1 are not included.

forms of MCDs are due to abnormal neuronal and glial proliferation caused by an aberrant activation of mTOR signalling cascade, as in tuberous sclerosis complex (TSC), which is caused by mutations in TSC1 and TSC2, encoding two interacting inhibitors of mTORC1 (figure 1). ${ }^{47}$ Furthermore, recent publications have demonstrated that somatic brain mutations are implicated in the pathogenesis of MCDs, as already recognised for tumour development in patients with TSC. . $^{41}{ }^{48-51}$ In FE families, MCDs may be observed in only a portion of the affected members carrying a germinal mutation in a GATOR1-encoding gene. ${ }^{38} 4041$ This might be explained by the limitations of conventional neuroimaging techniques, which may fail to detect subtle brain lesions. ${ }^{46}$ Alternatively, a 'two-hits model' has been proposed, by which a second brain somatic mutation in the same gene is hypothesised to be responsible for the development of MCD. Baulac et $a l^{40}$ studied a family, in which a DEPDC5 mutation segregated in all affected members. In one of the patients with FCD, they examined a lesional tissue specimen and found a brain somatic DEPDC5 mutation in addition to the germline hit. They suggested that this is consistent with a two-hit model leading to biallelic inactivation of the gene within the lesional tissue. However, there is still limited experimental evidence that this hypothesis, which has been proven valid for TSC1/TSC $2,{ }^{51}$ holds for genes of the GATOR1 complex. Most of the DEPDC5 mutations described so far are loss-of-function mutations (table 1), suggesting that the loss of the inhibition of mTORC1 activity could be the cause leading to epilepsy. The hyperactivation of mTORC1 has been also detected both with in vitro systems and in brain resections from GATOR1 mutated patients. ${ }^{19} 3842$ This latter point is of particular interest because an abnormal mTORC1 signalling is known to cause alterations in neuronal migration and cortical lamination, as reported in tuberous sclerosis ${ }^{52}$ and as documented in the heterozygous DEPDC5 rat model (Depdc $5^{ \pm}$) recently published. ${ }^{53}$ The functional assessment of 12 selected DEPDC5 variants identified in patients with $\mathrm{FE}$ has revealed 
Table 1 Published GATOR1 gene mutations and associated phenotypes.

\begin{tabular}{|c|c|c|c|c|}
\hline Gene & Nucleotide change & Protein change & Phenotype & References \\
\hline DEPDC5 & c. $21 \mathrm{C}>\mathrm{G}$ & p.Tyr7* & $F F E V F+B O S D$ & 1839 \\
\hline DEPDC5 & c. $1663 C>T$ & p.Arg555* & FFEVF+FCD & 1838 \\
\hline DEPDC5 & c.488_490delTGT & p.Phe164del & FFEVF & 18 \\
\hline DEPDC5 & c. $4107 \mathrm{G}>\mathrm{A}$ & p.Trp1369* & FFEVF, NFLE & 1837 \\
\hline DEPDC5 & c. $4606 \mathrm{C}>\mathrm{T}$ & p.GIn $1536^{*}$ & FFEVF & 18 \\
\hline DEPDC5 & c.1122delA & p.Leu374Phe fs ${ }^{*} 30$ & FFEVF & 16 \\
\hline DEPDC5 & c. $715 \mathrm{C}>\mathrm{T}$ & p.Arg239* & FFEVF & 1640 \\
\hline DEPDC5 & c. $1114 C>T$ & p.Gln372* & FFEVF & 16 \\
\hline DEPDC5 & $c .2527 C>T$ & p.Arg843* & FFEVF, FFE & 1836 \\
\hline DEPDC5 & c. $4397 \mathrm{G}>\mathrm{A}$ & p.Trp1466* & FFE & 18 \\
\hline DEPDC5 & c. $193+1 \mathrm{G}>\mathrm{A}$ & - & $F F E, E S+F E+I D+A S D$ & 1822 \\
\hline DEPDC5 & c. $279+1 \mathrm{G}>\mathrm{A}$ & - & $\mathrm{FFE}+\mathrm{SBH}$ & 1839 \\
\hline DEPDC5 & c. $1459 C>T$ & p.Arg $487^{*}$ & FFE, NFLE & 1837 \\
\hline DEPDC5 & c. $3802 C>T$ & p.Arg1268* & FFE & 18 \\
\hline DEPDC5 & c. $982 C>T$ & p.Arg $328^{*}$ & FTLE & 16 \\
\hline DEPDC5 & c. $4567 C>T$ & p.Gln1523* & ADNFLE & 16 \\
\hline DEPDC5 & c. $418 C>T$ & p.G $\ln 140^{*}$ & $\mathrm{FFE}+\mathrm{BOSD}$ & 39 \\
\hline DEPDC5 & c. $3311 C>T$ & p.Ser1104Leu & FFE & 18 \\
\hline DEPDC5 & c. $3217 A>C$ & p.Ser1073Arg & FFE & 18 \\
\hline DEPDC5 & c. $1355 C>T$ & p.Ala452Val & FFE, FCD & 1841 \\
\hline DEPDC5 & c. $1454 \mathrm{G}>\mathrm{A}$ & p.Arg485G $\ln$ & FTLE & 16 \\
\hline DEPDC5 & c.3417delA & p.lle1139Met fs*24 & FECTS & 21 \\
\hline DEPDC5 & c. $59-1 \mathrm{G}>\mathrm{C}$ & - & FECTS & 21 \\
\hline DEPDC5 & c. $2593 \mathrm{C}>\mathrm{T}$ & p.Arg $865^{*}$ & FECTS & 21 \\
\hline DEPDC5 & c. $727 C>T$ & p.Arg243* & FECTS, NFLE & 2120 \\
\hline DEPDC5 & $c .814 \mathrm{G}>\mathrm{T}$ & p.Val272Leu & FECTS & 21 \\
\hline DEPDC5 & c. $268 \mathrm{G}>\mathrm{A}$ & p.Val9olle & FECTS & 21 \\
\hline DEPDC5 & c. $3457 \mathrm{~A}>\mathrm{G}$ & p.Ser1153Gly & FECTS & 21 \\
\hline DEPDC5 & c. $2591 C>T$ & p.Thr864Met & FECTS & 36 \\
\hline DEPDC5 & c. $484-1 \mathrm{G}>\mathrm{A}$ & - & $\mathrm{FFE}+\mathrm{FCD}$ & 40 \\
\hline DEPDC5 & c. $1264 C>T$ & p.Arg $422^{*}$ & $\mathrm{FFE}+\mathrm{FCD}$, FLE & 2040 \\
\hline DEPDC5 & c. $1759 \mathrm{C}>\mathrm{T}$ & p.Arg587* & $\mathrm{FFE}+\mathrm{FCD}$ & 40 \\
\hline DEPDC5 & c.783_786delTGAG & p.Asn261 Lys fs ${ }^{*} 11$ & FCD & 41 \\
\hline DEPDC5 & c. $6241+1 \mathrm{G}>\mathrm{A}$ & - & FCD & 41 \\
\hline DEPDC5 & c.128_129insC & p.Asn45Gln fs ${ }^{\star} 3$ & HME & 41 \\
\hline DEPDC5 & c. $2355-2 A>G$ & - & NFLE & 37 \\
\hline DEPDC5 & c. $3259 C>T$ & p.Arg1087* & NFLE & 37 \\
\hline DEPDC5 & c.4112delT & p.Leu1371Arg fs*14 & EAF & 17 \\
\hline DEPDC5 & c. $.918 \mathrm{C}>\mathrm{G}$ & p.Tyr306* & EAF & 1743 \\
\hline DEPDC5 & c. $3265-3 C>T$ & - & TLE & 20 \\
\hline DEPDC5 & c.1092_1099insGGATTTGG & p.Val367Gly fs ${ }^{*} 40$ & FLE & 20 \\
\hline DEPDC5 & c. $1625 \mathrm{~A}>\mathrm{C}$ & p.Gln542Pro & FFE & 20 \\
\hline DEPDC5 & $c .526 \mathrm{C}>\mathrm{T}$ & p.G $\ln 176^{*}$ & NFLE & 20 \\
\hline DEPDC5 & c. $4033+5 A>G$ & - & TLE & 20 \\
\hline DEPDC5 & $c .3461 C>T$ & p.Ser1154Phe & TLE & 20 \\
\hline DEPDC5 & c.492delTCGTT & p.Arg165Tyr fs*14 & NFLE & 20 \\
\hline DEPDC5 & c. $3241 \mathrm{~A}>\mathrm{C}$ & p.Thr1081Pro & ECSWS & 20 \\
\hline DEPDC5 & c. $3696+5 G>A$ & - & FFE & 20 \\
\hline DEPDC5 & c. $435 \mathrm{G}>\mathrm{A}$ & p.Trp145* & NFLE & 20 \\
\hline DEPDC5 & c. $3994 C>T$ & p.Arg1332* & TLE & 20 \\
\hline DEPDC5 & c. $640 \mathrm{C}>\mathrm{G}$ & p.His214Asp & NFLE & 20 \\
\hline DEPDC5 & C. $161 \mathrm{~A}>\mathrm{C}$ & p.GIn54Pro & TLE & 20 \\
\hline DEPDC5 & c. $3803 \mathrm{G}>\mathrm{A}$ & p.Arg1268Gln & TLE & 20 \\
\hline DEPDC5 & c. $1909 C>T$ & p.Arg637* & NFLE & 20 \\
\hline DEPDC5 & c.985delA & p.Thr329Leu fs*7 & NFLE & 20 \\
\hline DEPDC5 & c.2390delA & p.Gln797Arg fs ${ }^{*} 18$ & $\mathrm{ES}+\mathrm{EE}+\mathrm{FCD}+\mathrm{ASD}$ & 22 \\
\hline DEPDC5 & c. $1555 C>T$ & p.G $\ln 519^{*}$ & $\mathrm{ES}+\mathrm{EE}+\mathrm{FLE}$ & 22 \\
\hline DEPDC5 & c. $3092 C>A$ & p.Pro1031His & $\mathrm{ES}+\mathrm{EE}$ & 22 \\
\hline DEPDC5 & $c .842 \mathrm{~A}>\mathrm{T}$ & p.Tyr281Phe & $\mathrm{ES}+\mathrm{EE}+\mathrm{FCD}$ & 22 \\
\hline
\end{tabular}


Table 1 Continued

\begin{tabular}{|c|c|c|c|c|}
\hline Gene & Nucleotide change & Protein change & Phenotype & References \\
\hline NPRL2 & c. 100 C>T & p.Arg34* & NFLE & 20 \\
\hline NPRL2 & c. $883 \mathrm{C}>\mathrm{T}$ & p.Arg295* & TLE & 20 \\
\hline NPRL2 & c. 329 C>G & p.Thr110Ser & TLE & 20 \\
\hline NPRL2 & c. $640 \mathrm{G}>\mathrm{C}$ & p.Asp214His & FLE & 20 \\
\hline NPRL2 & c. $314 \mathrm{~T}>\mathrm{C}$ & p.Leu105Pro & NFLE & 20 \\
\hline NPRL3 & c.835_836insT & p.Ser279Phe fs ${ }^{*} 52$ & NFLE & 20 \\
\hline NPRL3 & c.1376_1377insAC & p.Ser460Pro fs* 20 & $\mathrm{FE}+\mathrm{FCD}, \mathrm{TLE}$ & 1920 \\
\hline NPRL3 & c. $745 \mathrm{G}>\mathrm{A}$ & p.Glu249Lys & FFE & 20 \\
\hline NPRL3 & c. $275 \mathrm{G}>\mathrm{A}$ & p.Arg92Gln & $\mathrm{FE}+\mathrm{GE}+\mathrm{FCD}, \mathrm{FLE}$ & 1920 \\
\hline NPRL3 & c.954_955insCCCA & p.Trp319Pro fs*13 & TLE & 20 \\
\hline NPRL3 & $\begin{array}{l}\text { C. } 1352 \_1354 \text { delACAGins } \\
\text { TGACCCATCC }\end{array}$ & - & $\mathrm{FE}+\mathrm{FCD}$ & 19 \\
\hline
\end{tabular}

that only a portion has a clear effect on DEPDC5 signalling and mTORC1 activation, in terms of expression, GATOR1 complex formation, and interaction with active RagA/B-RagC/D heterodimers in vitro (see below). These findings then suggest that some of the identified GATOR1 variants could have distinct consequences on GATOR1 function that may explain the phenotypic variation observed among patients. ${ }^{42}$ Consequently, the finding of a hyperactivation of mTORC1 signalling in patients with GATOR1 mutations suggests a novel common pathological mechanism underlying FEs with or without MCDs: indeed these could be included in the so-called 'mTORopathies', with important implications both in patients' treatment and prognosis. However, since MCDs are not frequently found in GATOR1-associated epilepsies, further studies will be needed to elucidate the mechanism underlying MCD formation.

\section{GATOR1 SUBCOMPLEX FEATURES AND ITS ROLE IN THE MTOR PATHWAY}

DEPDC5 is located on chromosome $22 \mathrm{q} 12$ and encodes a 1603-amino acid protein, ubiquitously and constantly expressed both in the developing and in the adult brain, and characterised by two functional domains. ${ }^{18}$ The DUF3608 domain of the protein is thought to contribute to the interaction of the DEPDC5 homologue with the two other components of GATOR1 in yeast, ${ }^{54}$ but its function has not been characterised in mammals yet. The DEP domain, which was named after the initials of the proteins Disheveled, Egl-10 and Pleckstrin, is a globular domain found in numerous GTPase activating proteins. The DEP domain is also found in DEPTOR (a subunit of mTORC1) where it has a role in the interaction between RGS (regulator of $G$ protein signalling) proteins and their membranebound G-protein-coupled receptors. ${ }^{14} 55$ NPRL2 and NPRL3 are located on chromosomes $3 \mathrm{p} 21.3$ and $16 \mathrm{p} 13.3$ and encode two proteins of 380 and 569 amino acids, respectively. Both proteins are characterised by $\mathrm{N}$-terminal longin domains and PEST motifs. ${ }^{14}$ Longin domains are usually found in guanine nucleotide exchange factor (GEF) proteins; however, a GEF activity has not yet been demonstrated for these two proteins. ${ }^{56-58}$ On the other hand, PEST motifs are often found in rapidly degraded proteins, although these are not well conserved in mammals and could not elicit this function in NPRL2/
3. ${ }^{11} 14$ No three-dimensional (3D) map of the GATOR1 complex is available at present, but a recently published combination of biochemical and computational approaches has revealed the first 3D map of the yeast homologue of the mammalian GATOR complex, in which the two homologous subcomplexes form connected discrete modules, suggesting similar interactions between GATOR1 and GATOR2. ${ }^{14}{ }^{59}$ The GATOR complex is a key regulator of the cellular sensing of nutrients levels, through its regulation of mTORC1 activity, which plays a pivotal role in this signalling; however, this has not been well studied in neural systems. ${ }^{160}$ Figure 1 illustrates the main signalling cascades converging on mTOR regulation. In the past few years, GATOR1 was implicated in the inhibition of Rag GTPase heterodimers RagA/B-RagC/D, which are involved in mTORC1 recruitment at the lysosome membrane, a key step required for its phosphorylation and consequently activation by the small GTPase RHEB. ${ }^{10}{ }^{61}$ GATOR1 inhibition of RagA/B-RagC/D is blocked by GATOR2 activation. ${ }^{10}$ The outcome of the fine regulation of mTOR activity in the brain is the control of brain development and function. ${ }^{4-7}$

\section{NEUROLOGICAL DISORDERS RELATED TO MTOR PATHWAY DEREGULATION}

Given the multiple roles of mTOR pathway in brain homeostasis and development, it is not surprising that its deregulation has been implicated in several monogenic neurodegenerative and neuropsychiatric diseases. These include the already cited TSC, caused by mutations in TSC1 and TSC2, or the PTEN Hamartoma Tumor Syndromes (including Cowden syndrome, Lhermitte-Duclos disease and Bannayan-Riley-Ruvacalba syndrome) caused by mutations in PTEN; in all these cases the genetic defect leads to the hyperactivation of mTORC1. TSC and PTEN-mutated neurons have similar but not identical pathologic phenotypes, possibly reflecting subtle differences in the signalling that have yet to be discovered. Other neurodevelopmental disorders due to mTOR deregulation include epileptic encephalopathy, and neurodegenerative and psychiatric diseases. $^{6263}$ The present review underlines the role of mTOR hyperactivation in the major FE syndromes with or without MCDs (table 1). In particular, both germinal and somatic mutations have been reported in genes coding for different 
components of mTOR signalling, such as GATOR1 encoding genes, PIK3CA, AKT3 and MTOR itself. $^{7} 19334864$ Despite several evidences implicating the deregulation of mTOR pathway in the pathogenesis of epilepsy, the way in which it triggers epileptogenesis is still unknown. mTORC1 hyperactivation could contribute to aberrant circuit formation or alter already established neural circuits. Furthermore, as mTOR activity is regulated by several non-genetic factors, a combination of mutations in mTOR signalling genes and environmental factors could hyperactivate mTOR synergistically, representing a possible explanation for the variable phenotypes found in mTORopathies. ${ }^{62}$ Moreover, MCD-related epilepsies due to mutations in mTOR pathway genes often show early onset and poor response to pharmacological treatment. This could be partly explained by the fact that anticonvulsant medications represent only a symptomatic therapy, which does not address the underlying biological mechanism. The implication of mTOR signalling in a wide variety of lesional and non-lesional FEs is now promoting the development of targeted therapies based on mTOR inhibitors, which could significantly improve patients' treatment and prognosis. ${ }^{65}{ }^{66}$ In particular, the prototype drug for all mTOR inhibitors developed so far is rapamycin; some examples of available rapamycin analogues (rapalogs) are everolimus, temsirolimus and ridaforolimus. ${ }^{67} 68$ Second-generation mTOR inhibitors block the feedback activation of PI3K/AKT signalling acting as ATP-competitive mTOR kinase inhibitors; finally, drugs targeting downstream components of mTOR signalling pathway are being developed. ${ }^{68} 69$ Preclinical studies on animal models of TSC and other mTORopathies have shown a positive effect of rapamycin on the development of seizures and on seizure frequency, and early administration resulted also in a reduction of the alterations of cortical development. Moreover, clinical pharmacological trials on patients with TSC are now underway using rapalogs as everolimus, and first evidences support the potential role of this class of drugs, ${ }^{51}$ notwithstanding some concerns about the timing to obtain a curative effect and the possible associated side effects; the review by Citraro and colleagues ${ }^{70}$ comments on the last achievements of both preclinical and clinical trials using mTOR inhibitors to treat epilepsy or prevent epileptogenesis. Patients with refractory lesional epilepsy eligible for surgery, who carry mutations in mTOR pathway genes, represent a substantial challenge for the identification of the correct therapeutic strategy. For instance, it is still unknown whether germline mutations (which are present in every cell of the brain) underlie neural malfunctioning, which is more widespread than the focal lesion, as reported for TSC, where extended epileptogenic networks not restricted to tubers have been described. ${ }^{71}$ This implies that surgical resection of the detected EZ may not be sufficient to abolish seizures. Rare cases that underwent lesionectomy showed a good surgical outcome $;{ }^{40}$ however, more robust prognostic data are needed.

\section{CONCLUSIONS}

In this review, we outlined the role of GATOR1 mutations in FE. The involvement of DEPDC5, NPRL2 and NRPL3 genes in different lesional and non-lesional FEs is in contrast to the previous knowledge that mutations in specific genes are linked to epileptic syndromes in which seizures semiology suggested the main involvement of specific brain areas (as for LGI1 mutations in EAF, or neuronal nicotinic acetylcholine receptor in ADNFLE). The histological analysis of brain specimens in individuals with MCDs, as those found in TSC or GATOR1 mutated patients, shows the hyperactivation of mTOR pathway restricted to dysmorphic neurons, suggesting that even in those patients without a detectable MCD, the presence of a small group of dysmorphic neurons due to mTOR hyperactivation can elicit an epileptogenic effect. In those cases with a detectable MCD the excision of the EZ may represent a curative option, although the long-term outcome is still undefined. In pharmacoresistant patients, not eligible for surgery, the GATOR1/mTOR signalling represents a promising therapeutic target. Furthermore, as mTOR inhibitors have shown an anticonvulsant and an antiepileptogenic effect, this will open the way to a novel class of antiepileptic drugs that could reduce the neurological conditions derived by recurrent seizures when early administered to the patient.

Contributors SB wrote the first draft of the manuscript and designed the figures and table. All authors contributed to the critical reading and editing of the manuscript.

Funding We acknowledge Telethon Foundation (Grant GGP13200 to PT and TP) for financial support.

Competing interests None declared.

Provenance and peer review Not commissioned; externally peer reviewed.

\section{REFERENCES}

1 Laplante M, Sabatini DM. mTOR signaling in growth control and disease. Cell 2012;149:274-93.

2 Weber JD, Gutmann DH. Deconvoluting mTOR Biology. Cell Cycle 2012;11:236-48

3 Wong M. A critical review of mTOR inhibitors and epilepsy: from basic science to clinical trials. Expert Rev Neurother 2013;13:657-69.

4 Tang SJ, Reis G, Kang H, Gingras AC, Sonenberg N, Schuman EM. A rapamycin-sensitive signaling pathway contributes to long-term synaptic plasticity in the hippocampus. Proc Natl Acad Sci USA 2002;99:467-72.

5 Swiech L, Perycz M, Malik A, Jaworski J. Role of mTOR in physiology and pathology of the nervous system. Biochim Biophys Acta 2008;1784:116-32.

6 Takei N, Nawa H. mTOR signaling and its roles in normal and abnormal brain development. Front Mol Neurosci 2014;7:28.

7 Lasarge CL, Danzer SC. Mechanisms regulating neuronal excitability and seizure development following mTOR pathway hyperactivation. Front Mol Neurosci 2014;7:18.

8 Kim DH, Sarbassov DD, Ali SM, King JE, Latek RR, Erdjument-Bromage H, Tempst $P$, Sabatini DM. mTOR interacts with raptor to form a nutrient-sensitive complex that signals to the cell growth machinery. Cell 2002;110:163-75.

9 Fang Y, Vilella-Bach M, Bachmann R, Flanigan A, Chen J. Phosphatidic acid-mediated mitogenic activation of mTOR signaling. Science 2001;294:1942-5

10 Bar-Peled L, Chantranupong L, Cherniack AD, Chen WW, Ottina KA, Grabiner BC, Spear ED, Carter SL, Meyerson M, Sabatini DM. A Tumor suppressor complex with GAP activity for the Rag GTPases that signal amino acid sufficiency to mTORC1. Science 2013;340:1100-6.

11 Dokudovskaya S, Waharte F, Schlessinger A, Pieper U, Devos DP, Cristea IM, Williams R, Salamero J, Chait BT, Sali A, Field MC, Rout MP, Dargemont C. A conserved coatomer-related complex containing Sec13 and Seh1 dynamically associates with the vacuole in Saccharomyces cerevisiae. Mol Cell Proteomics 2011;10:M110.006478.

12 Wei Y, Lilly MA. The TORC1 inhibitors Nprl2 and Nprl3 mediate an adaptive response to amino-acid starvation in Drosophila. Cell Death Differ 2014;21:1460-8.

13 Neklesa TK, Davis RW. A genome-wide screen for regulators of TORC1 in response to amino acid starvation reveals a conserved Npr2/3 complex. PLoS Genet 2009;5: e1000515.

14 Dokudovskaya S, Rout MP. SEA you later alli-GATOR--a dynamic regulator of the TORC1 stress response pathway. J Cell Sci 2015;128:2219-28.

15 Tinuper P, Bisulli F, Cross JH, Hesdorffer D, Kahane P, Nobili L, Provini F, Scheffer IE, Tassi L, Vignatelli L, Bassetti C, Cirignotta F, Derry C, Gambardella A, Guerrini R, Halasz P, Licchetta L, Mahowald M, Manni R, Marini C, Mostacci B, Naldi I, Parrino L, Picard F, Pugliatti M, Ryvlin P, Vigevano F, Zucconi M, Berkovic S, Ottman R. Definition and diagnostic criteria of sleep-related hypermotor epilepsy. Neurology Published Online First: 15 April 2016.

16 Ishida S, Picard F, Rudolf G, Noé E, Achaz G, Thomas P, Genton P, Mundwiller E, Wolff M, Marescaux C, Miles R, Baulac M, Hirsch E, Leguern E, Baulac S. Mutations of DEPDC5 cause autosomal dominant focal epilepsies. Nat Genet 2013;45:552-5.

17 Pippucci T, Licchetta L, Baldassari S, Palombo F, Menghi V, D'Aurizio R, Leta C, Stipa C, Boero G, d'Orsi G, Magi A, Scheffer I, Seri M, Tinuper P, Bisulli F. Epilepsy with auditory features: a heterogenous and clinico-molecular disease. Neurol Genet 2015;1:e5. 
18 Dibbens LM, de Vries B, Donatello S, Heron SE, Hodgson BL, Chintawar S, Crompton DE, Hughes JN, Bellows ST, Klein KM, Callenbach PM, Corbett MA, Gardner AE, Kivity S, Iona X, Regan BM, Weller CM, Crimmins D, O'Brien TJ, Guerrero-López R, Mulley JC, Dubeau F, Licchetta L, Bisulli F, Cossette P, Thomas $P Q$, Gecz J, Serratosa J, Brouwer OF, Andermann F, Andermann E, van den Maagdenberg AM, Pandolfo M, Berkovic SF, Scheffer IE. Mutations in DEPDC5 cause familial focal epilepsy with variable foci. Nat Genet 2013;45: $546-51$.

19 Sim JC, Scerri T, Fanjul-Fernández M, Riseley JR, Gillies G, Pope K, van Roozendaal $\mathrm{H}$, Heng Jl, Mandelstam SA, McGillivray G, MacGregor D, Kannan L, Maixner W, Harvey AS, Amor DJ, Delatycki MB, Crino PB, Bahlo M, Lockhart PJ, Leventer RJ. Familial cortical dysplasia caused by mutation in the mammalian target of rapamycin regulator NPRL3. Ann Neurol 2016;79:132-7.

20 Ricos MG, Hodgson BL, Pippucci T, Saidin A, Ong YS, Heron SE, Licchetta L, Bisulli F, Bayly MA, Hughes J, Baldassari S, Palombo F; Epilepsy Electroclinical Study Group, Santucci M, Meletti S, Berkovic SF, Rubboli G, Thomas PQ, Scheffer IE, Tinuper P, Geoghegan J, Schreiber AW, Dibbens LM. Mutations in the mammalian target of rapamycin pathway regulators NPRL2 and NPRL3 cause focal epilepsy. Ann Neurol 2016;79:120-31.

21 Lal D, Reinthaler EM, Schubert J, Muhle H, Riesch E, Kluger G, Jabbari K, Kawalia A, Bäumel C, Holthausen H, Hahn A, Feucht M, Neophytou B, Haberlandt E, Becker $F$, Altmüller J, Thiele H, Lemke JR, Lerche $H$, Nürnberg $P$, Sander T, Weber $Y$, Zimprich F, Neubauer BA. DEPDC5 mutations in genetic focal epilepsies of childhood. Ann Neurol 2014;75:788-92.

22 Carvill GL, Crompton DE, Regan BM, McMahon JM, Saykally J, Zemel M, Schneider AL, Dibbens L, Howell KB, Mandelstam S, Leventer FJ, Harvey AS, Mullen SA, Berkovic SF, Sullivan J, Scheffer IE, Mefford HC. Epileptic spasms are a feature of DEPDC5 mTORopathy. Neurol Genet 2015;1:e17.

23 Ngugi AK, Kariuki SM, Bottomley C, Kleinschmidt I, Sander JW, Newton CR. Incidence of epilepsy: a systematic review and meta-analysis. Neurology 2011;77:1005-12.

24 Berg AT, Berkovic SF, Brodie MJ, Buchhalter J, Cross JH, van Emde Boas W, Engel J, French J, Glauser TA, Mathern GW, Moshé SL, Nordli D, Plouin P, Scheffer IE. Revised terminology and concepts for organization of seizures and epilepsies: report of the ILAE Commission on Classification and Terminology, 2005-2009. Epilepsia 2010;51:676-85.

25 Téllez-Zenteno JF, Hernández-Ronquillo L. A review of the epidemiology of temporal lobe epilepsy. Epilepsy Res Treat 2012;2012:630853.

26 Kalachikov S, Evgrafov O, Ross B, Winawer M, Barker-Cummings C, Martinelli Boneschi F, Choi C, Morozov P, Das K, Teplitskaya E, Yu A, Cayanis E, Penchaszadeh G, Kottmann AH, Pedley TA, Hauser WA, Ottman R, Gilliam TC. Mutations in LGI1 cause autosomal-dominant partial epilepsy with auditory features. Nat Genet 2002;30:335-41.

27 Dazzo E, Fanciulli M, Serioli E, Minervini G, Pulitano P, Binelli S, Di Bonaventura C, Luisi C, Pasini E, Striano S, Striano P, Coppola G, Chiavegato A, Radovic S, Spadotto A, Uzzau S, La Neve A, Giallonardo AT, Mecarelli O, Tosatto SC, Ottman $R$, Michelucci $R$, Nobile $C$. Heterozygous reelin mutations cause autosomal-dominant lateral temporal epilepsy. Am J Hum Genet 2015;96:992-1000

28 Heron SE, Smith KR, Bahlo M, Nobili L, Kahana E, Licchetta L, Oliver KL, Mazarib A, Afawi Z, Korczyn A, Plazzi G, Petrou S, Berkovic SF, Scheffer IE, Dibbens LM. Missense mutations in the sodium-gated potassium channel gene KCNT1 cause severe autosomal dominant nocturnal frontal lobe epilepsy. Nat Genet 2012;44:1188-90.

29 Steinlein OK, Mulley JC, Propping P, Wallace RH, Phillips HA, Sutherland GR, Scheffer IE, Berkovic SF. A missense mutation in the neuronal nicotinic acetylcholine receptor alpha 4 subunit is associated with autosomal dominant nocturnal frontal lobe epilepsy. Nat Genet 1995;11:201-3.

30 Aridon P, Marini C, Di Resta C, Brilli E, De Fusco M, Politi F, Parrini E, Manfredi I, Pisano T, Pruna D, Curia G, Cianchetti C, Pasqualetti M, Becchetti A, Guerrini R, Casari $\mathrm{G}$. Increased sensitivity of the neuronal nicotinic receptor alpha 2 subunit causes familial epilepsy with nocturnal wandering and ictal fear. Am I Hum Genet 2006;79:342-50

31 De Fusco M, Becchetti A, Patrignani A, Annesi G, Gambardella A, Quattrone A, Ballabio $A$, Wanke $E$, Casari $G$. The nicotinic receptor beta 2 subunit is mutant in nocturnal frontal lobe epilepsy. Nat Genet 2000;26:275-6.

32 Hildebrand MS, Tankard R, Gazina EV, Damiano JA, Lawrence KM, Dahl HH, Regan BM, Shearer AE, Smith RJ, Marini C, Guerrini R, Labate A, Gambardella A, Tinuper P, Lichetta L, Baldassari S, Bisulli F, Pippucci T, Scheffer IE, Reid CA, Petrou S, Bahlo M, Berkovic SF. PRIMA1 mutation: a new cause of nocturnal frontal lobe epilepsy. Ann Clin Transl Neurol 2015;2:821-30.

33 Steinlein OK. Genetic heterogeneity in familial nocturnal frontal lobe epilepsy. Prog Brain Res 2014;213:1-15.

34 Kaur A. Novel DEPDC5 mutations causing familial focal epilepsy with variable foci identified. Clin Genet 2013:84:341-2.

35 Malpass K. Epilepsy: Discovery of DEPDC5 mutations provides further evidence of a genetic link to inherited focal epilepsies. Nat Rev Neurol 2013; 9:237.
36 Martin C, Meloche C, Rioux MF, Nguyen DK, Carmant L, Andermann E, Gravel M, Cossette $P$. A recurrent mutation in DEPDC5 predisposes to focal epilepsies in the French-Canadian population. Clin Genet 2014;86:570-4.

37 Picard F, Makrythanasis P, Navarro V, Ishida S, de Bellescize J, Ville D, Weckhuysen S, Fosselle E, Suls A, De Jonghe P, Vasselon Raina M, Lesca G, Depienne C, An-Gourfinkel I, Vlaicu M, Baulac M, Mundwiller E, Couarch P, Combi R, Ferini-Strambi L, Gambardella A, Antonarakis SE, Leguern E, Steinlein O, Baulac S. DEPDC5 mutations in families presenting as autosomal dominant nocturnal frontal lobe epilepsy. Neurology 2014;82:2101-6.

38 Scerri T, Riseley JR, Gillies G, Pope K, Burgess R, Mandelstam SA, Dibbens L, Chow CW, Maixner W, Harvey AS, Jackson GD, Amor DJ, Delatycki MB, Crino PB, Berkovic SF, Scheffer IE, Bahlo M, Lockhart PJ, Leventer RJ. Familial cortical dysplasia type IIA caused by a germline mutation in DEPDC5. Ann Clin Trans/ Neurol 2015;2:575-80.

39 Scheffer IE, Heron SE, Regan BM, Mandelstam S, Crompton DE, Hodgson BL, Licchetta L, Provini F, Bisulli F, Vadlamudi L, Gecz J, Connelly A, Tinuper P, Ricos MG, Berkovic SF, Dibbens LM. Mutations in mammalian target of rapamycin regulator DEPDC5 cause focal epilepsy with brain malformations. Ann Neurol 2014:75:782-7.

40 Baulac S, Ishida S, Marsan E, Miquel C, Biraben A, Nguyen DK, Nordli D, Cossette $P$, Nguyen $S$, Lambrecq $V$, Vlaicu M, Daniau M, Bielle $F$, Andermann $E$, Andermann $F$, Leguern E, Chassoux F, Picard F. Familial focal epilepsy with focal cortical dysplasia due to DEPDC5 mutations. Ann Neurol 2015;77:675-83.

41 D'Gama AM, Geng Y, Couto JA, Martin B, Boyle EA, LaCoursiere CM, Hossain A, Hatem NE, Barry BJ, Kwiatkowski DJ, Vinters HV, Barkovich AJ, Shendure J, Mathern GW, Walsh CA, Poduri A. Mammalian target of rapamycin pathway mutations cause hemimegalencephaly and focal cortical dysplasia. Ann Neurol 2015:77:720-5.

42 van Kranenburg M, Hoogeveen-Westerveld M, Nellist M. Preliminary functional assessment and classification of DEPDC5 variants associated with focal epilepsy. Hum Mutat 2015;36:200-9.

43 Striano P, Serioli E, Santulli L, Manna I, Labate A, Dazzo E, Pasini E, Gambardella A, Michelucci $R$, Striano $S$, Nobile C. DEPDC5 mutations are not a frequent cause of familial temporal lobe epilepsy. Epilepsia 2015;56:e168-71.

44 Bisulli F, Licchetta L, Baldassari S, Pippucci T, Tinuper P. DEPDC5 mutations in epilepsy with auditory features. Epilepsia 2016;57:335.

45 Kabat J, Król P. Focal cortical dysplasia—review. Pol I Radiol 2012;77:35-43.

46 Lerner JT, Salamon N, Hauptman JS, Velasco TR, Hemb M, Wu JY, Sankar R, Donald Shields W, Engel I Jr, Fried I, Cepeda C, Andre VM, Levine MS, Miyata H, Yong WH, Vinters HV, Mathern GW. Assessment and surgical outcomes for mild type I and severe type II cortical dysplasia: a critical review and the UCLA experience. Epilepsia 2009;50:1310-35

47 Curatolo P, Moavero R, Roberto D, Graziola F. Genotype/phenotype correlations in tuberous sclerosis complex. Semin Pediatr Neurol 2015;22:259-73.

48 Lee JH, Huynh M, Silhavy JL, Kim S, Dixon-Salazar T, Heiberg A, Scott E, Bafna V, Hill KJ, Collazo A, Funari V, Russ C, Gabriel SB, Mathern GW, Gleeson JG. De novo somatic mutations in components of the PI3K-AKT3-mTOR pathway cause hemimegalencephaly. Nat Genet 2012:44:941-5.

49 Nakashima M, Saitsu H, Takei N, Tohyama J, Kato M, Kitaura H, Shiina M, Shirozu H, Masuda H, Watanabe K, Ohba C, Tsurusaki Y, Miyake N, Zheng Y, Sato T, Takebayashi H, Ogata K, Kameyama S, Kakita A, Matsumoto N. Somatic Mutations in the MTOR gene cause focal cortical dysplasia type Ilb. Ann Neurol 2015:78:375-86

50 Lim JS, Kim WI, Kang HC, Kim SH, Park AH, Park EK, Cho YW, Kim S, Kim HM, Kim JA, Kim J, Rhee H, Kang SG, Kim HD, Kim D, Kim DS, Lee JH. Brain somatic mutations in MTOR cause focal cortical dysplasia type II leading to intractable epilepsy. Nat Med 2015;21:395-400.

51 Curatolo P. Mechanistic target of rapamycin (mTOR) in tuberous sclerosis complex-associated epilepsy. Pediatr Neurol 2015;52:281-9.

52 Tsai V, Parker WE, Orlova KA, Baybis M, Chi AW, Berg BD, Birnbaum JF, Estevez J, Okochi K, Sarnat HB, Flores-Sarnat L, Aronica E, Crino PB. Fetal brain mTOR signaling activation in tuberous sclerosis complex. Cereb Cortex 2014;24:315-27.

53 Marsan E, Ishida S, Schramm A, Weckhuysen S, Muraca G, Lecas S, Liang N, Treins C, Pende M, Roussel D, Le Van Quyen M, Mashimo T, Kaneko T, Yamamoto T, Sakuma T, Mahon S, Miles R, Leguern E, Charpier S, Baulac S. Depdc5 knockout rat: A novel model of mTORopathy. Neurobiol Dis 2016;89:180-9.

$54 \mathrm{Wu}$ R, Wu H. A molecular chaperone mediates a two-protein enzyme complex and glycosylation of serine-rich streptococcal adhesins. J Biol Chem 2011;286:34923-31.

55 Ballon DR, Flanary PL, Gladue DP, Konopka JB, Dohlman HG, Thorner J. DEP-domain-mediated regulation of GPCR signaling responses. Cell 2006;126:1079-93.

56 Levine TP, Daniels RD, Wong LH, Gatta AT, Gerondopoulos A, Barr FA. Discovery of new longin and roadblock domains that form platforms for small GTPases in ragulator and TRAPP-II. Small GTPases 2013:4:62-9.

57 Nookala RK, Langemeyer L, Pacitto A, Ochoa-Montaño B, Donaldson JC, Blaszczyk BK, Chirgadze DY, Barr FA, Bazan JF, Blundell TL. Crystal structure of folliculin reveals a hidDENN function in genetically inherited renal cancer. Open Biol 2012;2:120071. 
58 Zhang $D$, lyer LM, He F, Aravind L. Discovery of novel DENN proteins: implications for the evolution of eukaryotic intracellular membrane structures and human disease. Front Genet 2012;3:283.

59 Algret R, Fernandez-Martinez J, Shi Y, Kim SJ, Pellarin R, Cimermancic P, Cochet E, Sali A, Chait BT, Rout MP, Dokudovskaya S. Molecular architecture and function of the SEA complex, a modulator of the TORC1 pathway. Mol Cell Proteomics 2014;13:2855-70.

60 Hara K, Yonezawa K, Weng QP, Kozlowski MT, Belham C, Avruch J. Amino acid sufficiency and mTOR regulate p70 S6 kinase and elF-4E BP1 through a common effector mechanism. J Biol Chem 1998;273:14484-94. Erratum in: J Biol Chem 1998:273:22160

61 Bar-Peled L, Sabatini DM. Regulation of mTORC1 by amino acids. Trends Cell Biol 2014:24:400-6.

62 Lipton JO, Sahin M. The neurology of mTOR. Neuron 2014;84:275-91.

63 Epi4K Consortium; Epilepsy Phenome/Genome ProjectAllen AS, Berkovic SF, Cossette P, Delanty N, Dlugos D, Eichler EE, Epstein MP, Glauser T, Goldstein DB, Han Y, Heinzen EL, Hitomi Y, Howell KB, Johnson MR, Kuzniecky R, Lowenstein DH, Lu YF, Madou MR, Marson AG, Mefford HC, Esmaeeli Nieh S, O'Brien TJ, Ottman R, Petrovski S, Poduri A, Ruzzo EK, Scheffer IE, Sherr EH, Yuskaitis CJ, Abou-Khalil B, Alldredge BK, Bautista JF, Berkovic SF, Boro A, Cascino GD, Consalvo D, Crumrine P, Devinsky O, Dlugos D, Epstein MP, Fiol M, Fountain NB, French J, Friedman D, Geller EB, Glauser T, Glynn S, Haut SR, Hayward J, Helmers SL, Joshi $S$, Kanner A, Kirsch HE, Knowlton RC, Kossoff EH, Kuperman R, Kuzniecky R, Lowenstein DH, McGuire SM, Motika PV, Novotny EJ, Ottman R, Paolicchi JM, Parent JM, Park K, Poduri A, Scheffer IE, Shellhaas RA, Sherr EH, Shih JJ, Singh R, Sirven J, Smith MC, Sullivan J, Lin Thio L, Venkat A, Vining EP, Von Allmen GK,
Weisenberg JL, Widdess-Walsh P, Winawer MR. De novo mutations in epileptic encephalopathies. Nature 2013;501:217-21.

64 Poduri A, Evrony GD, Cai X, Elhosary PC, Beroukhim R, Lehtinen MK, Hills LB, Heinzen EL, Hill A, Hill RS, Barry BJ, Bourgeois BF, Riviello JJ, Barkovich AJ, Black PM, Ligon KL, Walsh CA. Somatic activation of AKT3 causes hemispheric developmental brain malformations. Neuron 2012;74:41-8.

65 Meikle L, Pollizzi K, Egnor A, Kramvis I, Lane H, Sahin M, Kwiatkowski DJ. Response of a neuronal model of tuberous sclerosis to mammalian target of rapamycin (mTOR) inhibitors: effects on mTORC1 and Akt signaling lead to improved survival and function. J Neurosci 2008;28:5422-32.

66 Zeng LH, Xu L, Gutmann DH, Wong M. Rapamycin prevents epilepsy in a mouse model of tuberous sclerosis complex. Ann Neurol 2008:63:444-53

67 Abraham RT, Gibbons JJ, Graziani El. Chemistry and pharmacology of rapamycin and its derivatives. Enzymes 2010;27:329-66.

68 Zaytseva YY, Valentino JD, Gulhati P, Evers BM. MTOR inhibitors in cancer therapy. Cancer Lett 2012;319:1-7.

69 Pearce LR, Alton GR, Richter DT, Kath JC, Lingardo L, Chapman J, Hwang C, Alessi DR. Characterization of PF-4708671: a novel and highly specific inhibitor of p70 ribosomal S6 kinase (S6K1). Biochem J 2010;431:245-55.

70 Citraro R, Leo A, Constanti A, Russo E, De Sarro G. mTOR pathway inhibition as a new therapeutic strategy in epilepsy and epileptogenesis. Pharmacol Res 2016;107:333-43.

71 Jacobs J, Rohr A, Moeller F, Boor R, Kobayashi E, LeVan Meng P, Stephani U, Gotman J, Siniatchkin M. Evaluation of epileptogenic networks in children with tuberous sclerosis complex using EEG-fMRI. Epilepsia 2008;49: 816-25. 